\title{
An Ecosystem Service Value Model to Quantify Eco-environment Cost
}

\author{
Yi-Ru Wang ${ }^{1}$, Hui Zhang ${ }^{1}$ \\ ${ }^{1}$ Finance Department of International Business School, Jinan University, Zhuhai, China \\ Correspondence: Yi-Ru Wang, Finance Department of International Business School, Jinan University, Qianshan Road \\ 206\#, Zhuhai City, Guangdong Province, Post No.519070, China.
}

\author{
Received: April 2, $2020 \quad$ Accepted: April 16, $2020 \quad$ Available online: May 8, 2020 \\ doi:10.11114/aef.v7i4.4808 URL: https://doi.org/10.11114/aef.v7i4.4808
}

\begin{abstract}
With the development of society, ecological environmental protection has become more and more important. In this paper, an Ecosystem Service Value Model (ESVM) was developed to quantify the value of all types of ecosystem services. Through the ecosystem service value evaluation index system, we determined ecosystem service value equivalent factors of different ecosystem services. Then we combine the baseline value of the ecosystem service value equivalent factor to determine the ecosystem service value per unit area of different ecosystems. The amount of ecological service value reduction can be calculated with the amount of change in ecosystem area caused by land use projects. Ecological costs are equal to the reduction in the value of ecosystem services. The true economic cost of land use project consists of two parts: project construction cost and ecological cost. The model established in this paper considers the effects of time changes. And the introduction of dynamic adjustment of biomass changes and dynamic adjustment of currency changes make the model more adaptable to time changes. The research can evaluate the value of ecosystem services, which promotes the harmonious development of human and ecological environment.
\end{abstract}

Keywords: environmental economics, ecosystem service value model, ecological cost, land use project

\section{Introduction}

\subsection{Background}

In past, economic theory often ignores the impact of its decisions on the biosphere, or assumes that there are unlimited resources or capabilities available to them. This view is flawed and the environment is now facing consequences and ecosystem services may be limited or eliminated.

The impact of local small-scale changes in land use may seem negligible. While individually these activities may seem inconsequential to the total ability of the biosphere's functioning potential, cumulatively they are directly impacting the biodiversity and causing environmental degradation.

Traditionally, most land use projects do not consider the impact of, or account for changes to, ecosystem services. Now we try to put a value on the environmental cost of land use development projects, and consider environmental degradation in project costs. Then the true and comprehensive valuation of the project can be determined and assessed.

\subsection{Describe Relevant Scholarship}

Ecosystem services have extremely high or even incalculable values, and are closely related to human well-being. Fully evaluating the value of ecosystem services has become an urgent need for the implementation of policies such as ecosystem asset management, ecological compensation, and paid use of ecological services. In environmental economics, research questions about ecological value has always been focus of attention. In 1997, Costanza(Costanza,1997) published the article " The value of the world's ecosystem services and natural capital " in the journal Nature, which made the principles and methods of ecosystem service value estimation clear in a scientific sense. EgohB (EgohB,2007) thought, because the existing socio-economic system has not fully evaluated the value of ecosystem assets and their ecological services, ecosystem services have been regarded as abundant and inexhaustible free public services, resulting in scarcity of ecological service supply and excessive consumption of ecological services. Xie (Xie,2015) found that the economic values of 11 types of ecosystem services are accounted based on the expansion of labor value theory and using the method of equivalent value factor per unit ecosystem area. He fully demonstrates the relative scarcity of China's ecosystem service, especially in economically developed and densely populated areas. 
Ecosystem services and the accumulation of natural capital that generates this value are critical to the functioning of the Earth's life support system. It directly and indirectly provides human welfare, so it is very meaningful to study ecological value.

\subsection{Research Design}

Since ecosystems are critical to human survival and development, it is important to establish an effective model for researching various ecosystem services. First, we will establish an ecological service assessment model to quantify the value of ecosystem services. Next, we will give a calculation method of the real economic cost of the land use project. Finally, we need to explain how the model of this paper changes over time, considering time changes. We will address a series of issues between land open projects and the ecological environment.

\section{Models}

\subsection{Ecological Services Valuation Model (ESVM)}

As the basis of human survival and development, ecosystems play an important role in human production and life. For example, the decomposition of soil converts waste into inorganic salts for plant utilization. Ecosystem and its ecological processes continuously provide ecosystem goods and ecological services, thus forming the environmental and material basis of this model of this article.

Ecosystem services means products and services that are directly or indirectly obtained through the structure, processes, and functions of ecosystems, which is supplied to humans. Ecosystem services can create value, including value as a commodity and value as an ecological function. For example, the ability of providing wood as commodities is the commodity value of forests; the role of forests in conserving water sources and maintaining water and soil is the value created by forests as an ecological function. We refers to these two values collectively as the value of ecosystem services.

Therefore, based on the equivalent factor method, we establish an ecosystem services valuation model. The model quantifies the value of all types of ecosystem services. In the process of land use projects, the use of land is often changed and the original ecosystem is affected. Changing the original ecosystem will lead to changes in the value of ecosystem services. Based on the ecosystem services valuation model, we consider that the ecological cost is equal to the reduction of ecosystem service value.

It is important to note that the ecological cost is also considered as the cost of environmental degradation.

\subsubsection{The Types of Ecosystem Services}

In order to calculate the value of different types of ecosystem in a more precise and accurate way, we classifies the types of ecosystem services. Ecosystem services come in many different forms. To assess the value of ecosystem services, firstly it is necessary to break down complex structures and processes into a limited number of functions. These functions include resource supply, environmental regulation, cultural entertainment, and production support, and humans can obtain direct and indirect benefits from them. After refering to the related literature of Ding Lilian et al (Ding Lilian et al,2019), we summarize the existing types of ecosystem services that have been identified, and obtains Figure 2.1.

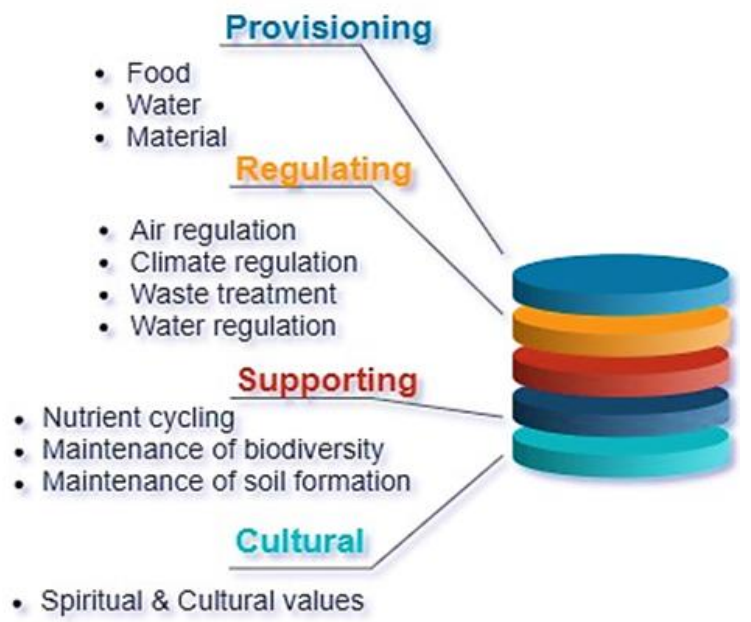

Figure 2.1. Ecosystem services 
In Figure 2.1, first, the ecosystem services are summarized into four types including Provisioning, Regulating, Supporting, and Cultural services. Further 11 sub-types are classified under the primary type. Among them, Provisioning include three types of food, water and material; Regulating include four sub-types of air regulation, climate regulation, water treatment, and water regulation; Supporting includes three sub-types nutrient cycling, maintenance of biodiversity and maintenance of soil formation; Cultural mainly provide one secondary type of spiritual and cultural value.

\subsubsection{Ecosystem Services Value Analysis Method}

The accounting methods for the value of ecosystem services mainly include the Contingent Valuation Method, the market value method, the travel expense method, the opportunity cost method, the shadow engineering method and the hedonic price method. For example, Ezebilo (Ezebilo,2016) used the tourist cost method to evaluate the recreational value of Swedish residents to natural landscapes. Sander (Sander,2012) used the hedonic price method to evaluate the influence of land cover types on the sales price of houses in a certain area of the United States, so as to provide reference for regional planning. Based on the reference to relevant literature, we use the ecosystem-based unit area value equivalent factor method to assess ecological value. First, we must formulate an ecosystem equivalent factor table to obtain the ecological value per unit area of different ecosystems, and then calculate the value of ecosystem services.

In order to determine the value of the value equivalent factor, we establishes the following specific evaluation index system of ecological environment service value. The evaluation index system proposes specific ecosystem service value evaluation indicators for 11 types of ecosystem services. The evaluation index system is shown in Table 2.1.

Table 2.1. Ecosystem service value evaluation index system

\begin{tabular}{lll}
\hline $\begin{array}{l}\text { Primary } \\
\text { indicator }\end{array}$ & $\begin{array}{l}\text { Secondary } \\
\text { indicators }\end{array}$ & Specific indicators \\
\hline \multirow{4}{*}{ Provisioning } & Food & Crop yield \\
\cline { 2 - 3 } & & Forage yield \\
\cline { 2 - 3 } & Water & Aquatic product yield \\
\cline { 2 - 3 } Regulating & Material & Biomass per unit area \\
\cline { 2 - 3 } & Air regulation & $\begin{array}{l}\text { Fust absorption number of Natural } \\
\text { Vegetation }\end{array}$ \\
\cline { 2 - 3 } & Climate regulation & Carbon fixation and oxygen release \\
\cline { 2 - 3 } Supporting & Waste treatment & Vegetation coverage \\
\cline { 2 - 3 } & Water regulation & Wetlands and alluvial plains area \\
\hline & Nutrient cycling & Net ecosystem carbon exchange \\
\cline { 2 - 3 } & $\begin{array}{l}\text { Maintenance of } \\
\text { biodiversity }\end{array}$ & Number of animal \& plant species \\
\cline { 2 - 3 } & $\begin{array}{l}\text { Maintenance of soil } \\
\text { formation }\end{array}$ & Soil retention rate \\
\hline Cultural & $\begin{array}{l}\text { Spiritual \& Cultural } \\
\text { values }\end{array}$ & Number of World Natural Heritage \\
\hline
\end{tabular}

\subsubsection{Ecosystem Service Value Calculation Method}

(1) Develop an ecosystem service value equivalent factor table $\left(\omega_{i j}\right)$

The ecosystem service value equivalence factor refers to the potential capacity of the relative contribution of ecosystem services to ecosystem services. Based on the contribution of various ecological services of other ecosystems to the value of farmland, the value of ecological services of other types of ecosystems is weighted, and other ecosystem service value equivalent factors are obtained.

The following is a specific method for deriving the equivalent table. First, using remote sensing data and meteorological 
data, the values of the specific indicators of cropland ecosystems in Table 2-1 above are obtained. Then, the indicator data of other ecosystems are compared with the indicator data of the cropland ecosystem to make weight assignment, and the equivalent factors of different types of ecosystems and service values of different types of ecosystems $\left(\omega_{i j}\right)$ are obtained. $\omega_{i j}$ is the equivalent factor value of the $\mathrm{i}$-th ecological service function of the $\mathrm{j}$-th ecosystem. It is important to note that because different regions have different ecosystems, even the same ecosystems may differ due to differences in time and latitude and longitude. Therefore, the data of the equivalent factor table should be derived according to the regional data.

(2) Calculate the baseline value of the ecosystem service value equivalent factor

Gao et al. (2018) argued the baseline value defining the value equivalence factor for an ecosystem service is $1 / 7$ of the economic value of food produced per unit area of farmland in that year. The baseline value of the ecosystem service value equivalence factor refers to the value of ecosystem services that can be created per unit area of cropland. The formula for calculating the baseline value of the ecosystem service value equivalence factor is as follows:

$$
V_{a}=\frac{1}{7} \sum_{i=1}^{n} \frac{s_{i} p_{i} q_{i}}{S}(i=1,2,3, \cdots, n)
$$

Where:

$V_{a}=$ the baseline value of an ecosystem service value equivalence factor,

$i=$ the crop species, $p_{i}=$ the average price of the crop in the region,

$q_{i}=$ the yield per unit area of the i-th crop, $s_{i}=$ the area of the i-th crop,

$S=$ the total area of $\mathrm{n}$ crops, $1 / 7$ means that the value provided by natural ecosystems without manpower inputs is $1 / 7$ of the economic value of food production services provided by existing cropland per unit area.

(3) Calculate the ecosystem services value

Step1. Determine the type of ecosystem and type of ecosystem services in the area studied

Step2. Based on the equivalent factor table $\left(\omega_{i j}\right)$, combined with the baseline value of one ecosystem service value equivalent factor in the region $\left(V_{a}\right)$, the ecosystems service value coefficients is obtained $V_{i j}$.

Step3. Based on the area of the ecosystem in the area studied, calculate the ecosystem services value (ESV).

The formula is as follows:

Where:

$$
\begin{gathered}
V_{i j}=\omega_{i j} \times V_{a} \\
E S V=\sum_{i=1}^{n} \sum_{j=1}^{m} A_{j} V_{i j}(i=1,2, \cdots, n ; j=1,2, \cdots, m)
\end{gathered}
$$

$i=$ the type of an ecosystem service; $j=$ the type of the ecosystem.

$V_{i j}=$ ecosystems service value coefficients of the $\mathrm{i}$-th ecological service of the $\mathrm{j}$-th ecosystem;

$\omega_{i j}=$ the equivalent factor value of the $\mathrm{i}$-th ecological service function of the $\mathrm{j}$-th ecosystem.

$A_{j}=$ the area of the $\mathrm{j}$-th ecosystem.

$\mathrm{ESV}=$ the total value of ecosystem services.

\subsection{True Economic Cost of Land Use Projects}

When considering ecosystem services, the economic cost of land use projects is mainly composed of two parts: project construction cost and environmental cost. Among them, the project construction cost refers to the actual economic cost required for the land use project required for road construction. Ecological cost refers to the reduction in the value of ecological services brought about by the change of ecosystems caused by the construction of land use projects. This cost is due to ecological damage caused by human activities. Therefore, in consideration of the ecological environment, the true cost of land use projects can be expressed as:

$$
C_{T E C}=C_{C O N S T}+C_{E C}
$$

Where:

$$
C_{T E C}=\text { the true economic cost, } C_{C O N S T}=\text { the construction cost, } C_{E C}=\text { the ecological cost. }
$$




\subsubsection{The Method to Calculate the Construction Cost}

Construction cost refers to the actual economic costs required for land use projects, such as workers' wages, material costs, equipment rental fees, etc. required to build roads. According to the "Construction Engineering Volume Calculation Principle (International)" revised by the Royal Institution of Chartered Surveyors in 1979, the construction cost of a project shall include: 1. labor and related expenses; 2. materials, goods and all related expenses; Provision of mechanical equipment; 4. Temporary works; 5. Opening fees, management fees, etc.; 6. Others.

$$
C_{\text {CONST }}=\sum_{i=1}^{n} C_{i}
$$

Where $C_{\text {CONST }}=$ the construction cost, $C_{i}=$ different types of construction costs.

\subsubsection{The Method to Calculate the Ecological Cost}

Ecological cost refers to the reduction in the value of ecological services brought about by ecosystem changes caused by the construction of land use projects. In the process of building a land project, land use is often changed and the original ecosystem is affected. For example, the development of cultivated land around the city as a building area has led to disappearance of the ecological services provided by the original cropland ecosystem and the value of cropland ecological services has decreased. This is the ecological cost of this land use project. Ecological cost is equal to the reduction in the value of ecosystem services.

Thus, the ecological cost of land use projects can be measured by the amount of change in value, which is: :

$$
C_{E C}=\Delta E S V
$$

Where : $C_{E C}=$ the ecological cost,

$\triangle E S V=$ the amount of change in the value of ecosystem services due to changes in land types.

\section{Case Study}

\subsection{Calculate the Ecological Cost}

In this section, we calculate the ecological cost of the Yangtze River Delta urban agglomeration development planning project. The relevant data of the region within the planning range of the Yangtze River Delta from 2000 to 2015 will be selected. The period from 2000 to 2015 will be divided into three time periods, and each time period will be 5 years for research.

\subsubsection{The Change in Land Type Area}

We collected data on land type changes in the region within the planning range of the Yangtze River Delta from 2000 to 2015, as shown in Figure 3.1.

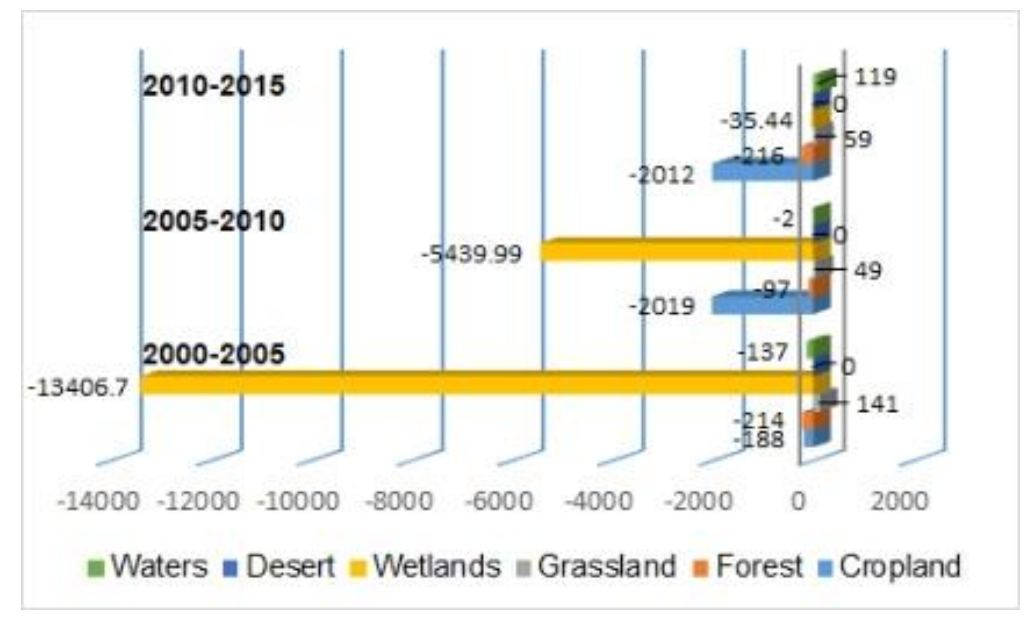

Figure 3.1. Change of land type area in the Yangtze River Delta region from 2000 to 2015 


\subsubsection{The Baseline Value of Equivalent Factor}

To calculate the baseline value of equivalent factor $\mathrm{Va}$, we selected relevant data for China from 2000 to 2015. The period from 2000 to 2015 is divided into three time periods, and each time period is 5 years for research. Calculate the unit price of the baseline value of equivalent factor at different times $(\mathrm{Va})$, as shown in table 3.1.

Table 3.1. The baseline value of equivalent factor from 2000 to 2015

\begin{tabular}{ccccccc}
\hline Years & $\begin{array}{c}\text { Wheat yield per } \\
\text { unit area }(\mathbf{K g} / \mathbf{h a})\end{array}$ & $\begin{array}{c}\text { Wheat price } \\
(\text { Yuan/Kg) }\end{array}$ & $\begin{array}{c}\text { Rice yield per } \\
\text { unit area }(\mathbf{K g} / \mathbf{h a})\end{array}$ & $\begin{array}{c}\text { Rice price } \\
(\text { Yuan/Kg) }\end{array}$ & $\begin{array}{c}\text { Cropland } \\
(\text { ha })\end{array}$ & Va \\
\hline $\mathbf{2 0 0 0 - 2 0 0 5}$ & 3963.32 & 1.335 & 6209.225 & 1.84 & 188 & $\mathbf{1 6 7 2}$ \\
$\mathbf{2 0 0 5 - 2 0 1 0}$ & 4620.98 & 1.55 & 6445.598 & 1.96 & 2019 & $\mathbf{1 9 8 0}$ \\
$\mathbf{2 0 1 0 - 2 0 1 5}$ & 5043.93 & 2.11 & 6739.828 & 2.82 & 2012 & $\mathbf{2 9 6 5}$ \\
\hline
\end{tabular}

Note: The data of each time period is represented by the average of each year.

\subsubsection{Ecosystem Services Value Coefficients}

We cites the China Ecosystem Services Value Equivalent Factor Table proposed by Xie Gaodi in 2015. The table has been studied in detail for the ecosystem services in China. The equivalent table is detailed in the appendix.

By calculation, the ecosystems service value coefficients are shown in table 3-2.

Table 3.2. The ecosystems service value coefficients

\begin{tabular}{lcccccc}
\hline $\begin{array}{l}\text { Ecosystem } \\
\text { services }\end{array}$ & Cropland & Forest & Grassland & Wetland & Desert & waters \\
\hline Food & 184712 & 42208 & 39004 & 85252 & 836 & 66864 \\
$\begin{array}{l}\text { Material } \\
\text { Water }\end{array}$ & -218405 & 50208 & 31798 & 433463 & 1674 & 874456 \\
$\begin{array}{l}\text { Air regulation } \\
\text { Climate }\end{array}$ & 149039 & 319430 & 202068 & 318174 & 10885 & 79544 \\
$\begin{array}{l}\text { regulation } \\
\text { Waste treatment }\end{array}$ & 22634 & 280411 & 176602 & 603576 & 34370 & 478669 \\
$\begin{array}{l}\text { Water regulation } \\
\text { Maintenance of }\end{array}$ & 250801 & 626584 & 391999 & 4064826 & 20131 & 9173959 \\
soil formation & 87287 & 389855 & 246754 & 387757 & 12590 & 78055 \\
$\begin{array}{l}\text { Nutrient cycling } \\
\text { Maintenance of }\end{array}$ & 26034 & 29813 & 19035 & 30233 & 840 & 5879 \\
biodiversity & 28570 & 355447 & 224640 & 1322633 & 11764 & 215117 \\
$\begin{array}{l}\text { Spiritual } \quad \& \\
\text { Cultural values }\end{array}$ & 12612 & 155968 & 99214 & 795397 & 5045 & 166478 \\
Total & 662179 & 3303285 & 2023059 & 8728156 & 109021 & 11395354 \\
\hline
\end{tabular}

By calculation, the ecological cost in each period is 11.868(2000-2005),5.791(2005-2010),0.159(2010-2015). (Unit:billion)

\subsubsection{Ecosystem Services Value Coefficients}

In the following sections, we will consider the cost-benefit analysis of the Yangtze River Delta urban agglomeration development planning project based on the ecological cost.

(1) True economic cost 
In 2.2, we established a calculation model of true economic cost. In this national planning and development project, the project construction cost is represented by statistical macro data, which is mainly composed of infrastructure construction cost and real estate development investment cost.

- Infrastructure construction costs refer to the total cost of construction for social services, energy power, water conservancy projects, and transportation construction. The construction of social services refers to the construction of schools and hospitals; the energy and power aspects include the construction of oil pipelines, the construction of natural gas pipelines, the construction of high-voltage motor stations, etc.; the water conservancy projects include the construction of reservoirs, dams, etc.; transportation includes roads, railways, etc. Airport, port, etc.

- Real estate development investment cost refers to the cost of building residential buildings and office commercial buildings during the urban development process.

(2) Project benefit

The goal of the Yangtze River Delta Urban Agglomeration Development Plan is to build a world-class urban agglomeration with a vibrant economy, high-end talent pooling, a rising ability to innovate, and efficient use of space. The construction of the project is conducive to the promotion of population urbanization, economic urbanization and social urbanization. The transfer of population on urban land, the accumulation of economic factors and the improvement of social welfare have brought about the recombination of various production factors on urban land, and improved the optimal allocation of urban land resources, bringing various benefits.

The benefits of the land use project can represent three aspects of economic, social and ecological benefits arising from the allocation of land resources. Economic benefits include increased regional GDP, increased rational allocation of industries, etc.; social benefits include increased social innovation capacity, improved people's quality of life, and scientific and cultural development; ecological benefits include the construction of urban parks, the construction of biological conservation research institutions, and the expansion of the benefits of urban green space and other benefits.

In the actual calculation, because other benefits are difficult to quantify, and economic benefits are undoubtedly the most intuitive benefits, the data is also relatively easy to obtain. Therefore, only the economic benefits of the project are listed here. In fact, the actual benefits of the project will be greater than its economic benefits. We chose to use the added value of the gross economic product (GDP) between 2000 and 2015 in the area covered by the project to indicate the economic benefits of the project. Because the construction cost in urban construction is a one-time investment, and the economic benefits are accumulated over time, it may continue to grow in many years to come. Although the GDP growth value of each year may be less than the cost of a one-time investment, it can also reflect the economic benefits of the project to a certain extent.

(3) Cost-benefit analysis

Based on the above, the cost-benefit analysis of the Yangtze River Delta urban agglomeration development planning project is shown in Figure 3-2.

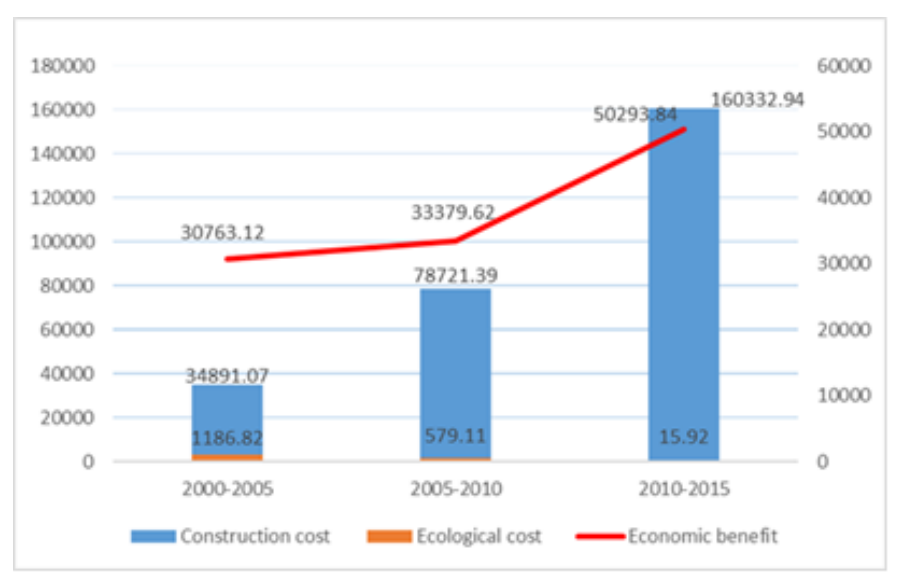

Figure 3.2. Cost benefit analysis of China Yangtze River Delta Urban Agglomeration Development Planning Project

It can be seen from the figure that in the early stage of project construction (2000-2005), due to the lack of consideration of the impact on the environment, large-scale expansion of urban area, resulting in high ecological costs. As time goes by, the Chinese government attaches importance to ecological environmental protection, and the intensity of land development is effectively controlled. As a result, ecological costs are declining and the benefits of the project 
are increasing. At the same time, the quality of the ecological environment in the region has generally improved, and regional environmental issues have been effectively addressed.

\section{Effectiveness Evaluation of the Model}

\subsection{Model Analysis}

The ecosystem service value model established in this paper is based on the unit area value equivalent factor method to obtain the unit area value of different ecosystems, and then the ecosystem service value. This model covers the direct use value and indirect use value of the ecosystem. This model is suitable for ecological value assessments at various scales, such as global, national, urban, and project assessments. In addition, this model can also be used to reveal the characteristics of ecosystem changes in time and space.

In practical applications, more accurate land use data can be obtained by means of GIS, and the data is easily available. In the evaluation process, the model has less data requirements, the calculation model is simple and easy to operate, the evaluation scope is comprehensive, and the results are easy to compare. The method has adaptability, and can adjust the equivalent factor according to different regional characteristics to adapt to the particularity of different regions. Therefore, from the perspective of the calculation method of ecosystem service value, the model established in this paper is effective.

\subsection{Sensitivity Analysis of the Model}

We use the Coefficient of Sensitivity to determine the dependence of ecosystem service value on the change of ecosystem value coefficient over time. If CS>1, it means that ESV is flexible to $\mathrm{V}$.The change of $1 \%$ of the independent variable will cause the variation of the dependent variable to be greater than $1 \%$, then the accuracy is poor and the reliability is low; if CS <1, it means that ESV is inelastic to $\mathrm{V}$. The result is credible.

The sensitivity index is calculated as follows:

$$
C S=\left|\frac{\left(E S V_{j}-E S V_{i}\right) / E S V_{i}}{\left(V_{j k}-V_{i k}\right) / V_{i k}}\right|
$$

Where:

$\mathrm{ESV}=$ ecosystem service value. $E S V_{j}=$ ecosystem service initial value.

$E S$ V $=$ ecosystem service adjusted value.

$V_{\mathrm{ik}}=$ The value of the $\mathrm{i}$-th service function of land use type $\mathrm{k}$.

In this paper, the ecological value coefficient of land use type is mobilized by $50 \%$ to analyze the change of ecosystem service value and the sensitivity to the value coefficient (taking the Yangtze River Delta as an example). The results are shown in Table 4-1 below.

Table 4.1. Sensitivity analysis results

\begin{tabular}{ccccccc}
\hline $\begin{array}{c}\text { Ecosystems } \\
\text { type }\end{array}$ & filed & forest & grassland & wetlands & unused land & waters \\
\hline CS & 0.0011 & 0.0059 & 0.0024 & 0.9823 & 0.0000 & 0.0131 \\
\hline
\end{tabular}

It can be concluded from the results that the CS of each item is lower than 1, indicating that the result is credible. Moreover, according to the weight of ecosystem service value, the order of weight is: wetland $>$ waters $>$ forest $>$ grassland $>$ farmland, which is in line with the importance of different types of ecosystems in the real world. Therefore, from the results of sensitivity analysis, the model established in this paper is highly effective.

\section{Further Exploration}

\subsection{The Changing Model Over Time}

The ecosystem has numerous services and functions. According to the principles of ecological economics, the value of ecosystem services is the sum of the values of each service in a stable period of time. The value of ecosystem services varies with time and space. In different regions, the relationship between the value of ecosystem services and economic development is also quite different. Therefore, for a given study area, we have considered time changes in this model. Specifically embodied in the following points: 
(1) Equivalent factors in the ecosystem service value equivalent factors table will change annually as the actual situation occurs.

(2) The value of the equivalent factors is measured by the average annual yield of grain and the average grain price.

However, these points are not enough to perfectly reflect the changes of the model over time. In order to make the model more perfect, we make the following improvements to make the model better applicable in time changes.

\subsubsection{Dynamic Adjustment of Time}

(1) Dynamic adjustment of biomass changes

Since the ecosystem is a system that changes with time, the essence of change is the change in the amount of ecological resources. The biophysical parameter that characterizes the amount of resources is the biomass of plants. The change of biomass is the response of vegetation growth, and it is also the main indicator that changes the value of ecosystem services. Therefore, we define Dynamic adjustment of biomass changes $\beta$ :

$$
\beta=\frac{M_{b}}{M_{i}}
$$

In the formula: $M_{b}$ is Background annual biomass; $M_{i}$ is No monitoring of biomass. The biomass of different years was calculated by remote sensing inversion method.

(2) Dynamic adjustment of currency changes

For the services and functions of ecosystem services, the prices of services provided, such as the price of livestock products, the price of forest trees, etc., change over time. This change affects the change in the value of the ecosystem, which is the change in the value of the currency, that is, the value of inflation in the monetary value of the ecosystem. Although wheat prices will change over time in the model, wheat prices do not reflect objective inflation levels as most countries use agricultural product price maintenance systems to protect agriculture from economic fluctuations. The most commonly used measure of the overall price level is the consumer price index, so the model needs to be multiplied by the household consumption index $\gamma$.

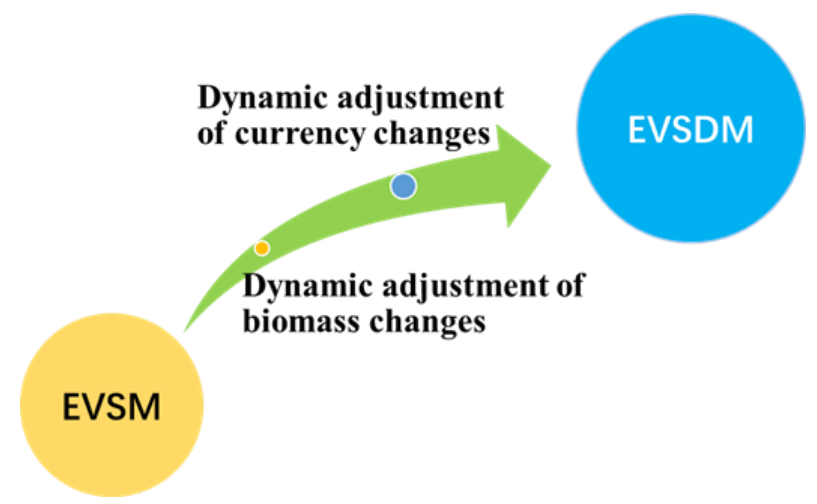

Figure 5.1. The ecosystem service value assessment model

\subsubsection{The Improved Ecosystem Service Value Evaluation Model}

(1) Dynamic adjustment of biomass changes

Combined with Dynamic adjustment of biomass and currency changes, the ecosystem service value assessment model is further improved, and the improved ecosystem service value evaluation model is obtained, as shown in Figure 5-1.

After considering time changes, the dynamic ecosystem service value model is:

$$
\begin{aligned}
& D V_{i j}=\beta \cdot \gamma \cdot V_{i j} \\
& E S V=\sum_{i=1}^{n} \sum_{j=1}^{m} A_{j} D V_{i j}(i=1,2, \cdots, n ; j=1,2, \cdots, m)
\end{aligned}
$$

Where:

$i=$ Ecosystem type, $j=$ Ecological service type 
$V_{i j}=$ The value of the $\mathrm{i}$-th service function of land use type $\mathrm{k}$.

$D V_{i j}=$ The value of the $\mathrm{i}$-th service function of land use type $\mathrm{k}$ change over time

$A_{j}=$ the - th Ecosystem area, ESV=Total value of ecosystem services

\section{Conclusion}

Through the analysis of ecosystem services, we establish an Ecosystem Service value Model (ESVM) to quantify the value of all types of ecosystem services. Next, we give the calculation method of the ecological cost of the land use project which is equal to the reduction of the ecosystem service value. Then, we conduct a cost-benefit analysis of different land use projects based on the model. This paper analyzes the China Yangtze River Delta Urban Agglomeration Development Planning Project. We also analyze how the model changes over time and further builds a dynamic ecosystem service value assessment model. Finally, we further expand the model. Based on the ecological cost, the concept of repair cost is proposed. Ecosystems play a vital role in the survival and development of human beings. It is unwise to make economic development at the expense of the environment. Human activities and land use projects should consider ecological costs. The harmonious development of man and nature is the goal of all of us.

\section{References}

Costanza, R. (1997). The value of the world's ecosystem services and natural capital [J]. Nature, 387(6630), 253-260. https://doi.org/10.1038/387253a0

Ding, L. L., Wang, Q., Chen, X., (2019). Tang Jianjun.Response of ecosystem service value to land use change in Dianshan Lake area from 1984 to 2014[J/OL]. Acta Ecologica Sinica, 2019(08), 1-12.

EgohB, Rouget, M., \& Reyers, B. (2007). etal.Integrating ecosystem services into conservation assessment: Areview [J]. Ecological Economics, 63(4), 714-721. https://doi.org/10.1016/j.ecolecon.2007.04.007

Ezebilo, E. E. (2016). Economic value of a non-market ecosystem service: an application of the travel cost method to nature recreation in Sweden[J]. International Journal of Biodiversity Science Ecosystem Services \& Management, 2016,12(4), 1-14. https://doi.org/10.1080/21513732.2016.1202322

Gao, Z. B., \& Wang, X. L. et al. (2018). Study on ecological compensation of Dongjiang River Basin based on ecosystem service value assessment [J]. Journal of Ecology and Rural Environment, 34(06), 563-570.

Heather, A. S., \& Robert, G. H. (2012). Estimating the economic value of cultural ecosystem services inan urbanizing area using hedonic pricing [J]. Journal of Environmental Management, 113(113C), 194-205. https://doi.org/10.1016/j.jenvman.2012.08.031

Xie, G. D., Zhang, C. X., Zhang, C. S., Xiao, Y., \& Lu, C. X. (2015). The Value of China's Ecosystem Services [J]. Resources Science, 37(09), 1740-1746. 
Appendix

China Ecosystem Services Value Equivalent Factor

\begin{tabular}{|c|c|c|c|c|c|c|c|c|c|c|c|c|c|c|}
\hline $\begin{array}{c}\text { Primary } \\
\text { clafication }\end{array}$ & \multicolumn{2}{|c|}{ cropland } & \multicolumn{4}{|c|}{ forest } & \multicolumn{3}{|c|}{ grassland } & \multirow{2}{*}{$\begin{array}{c}\text { wetland } \\
\mathrm{s}\end{array}$} & \multicolumn{2}{|c|}{ desert } & \multicolumn{2}{|c|}{ waters } \\
\hline $\begin{array}{c}\text { secondary } \\
\text { classification }\end{array}$ & $\begin{array}{l}\text { dry } \\
\text { farm }\end{array}$ & $\begin{array}{l}\text { wet } \\
\text { field }\end{array}$ & $\begin{array}{l}\text { conifero } \\
\text { us forest }\end{array}$ & $\begin{array}{l}\text { thero } \\
\text { pence } \\
\text { drymi } \\
\text { on }\end{array}$ & $\begin{array}{c}\text { broad } \\
\text {-leav } \\
\text { ed } \\
\text { forest }\end{array}$ & $\begin{array}{l}\text { shrub } \\
\text { forest }\end{array}$ & $\begin{array}{c}\text { gras } \\
\text { slan } \\
\text { ds }\end{array}$ & $\begin{array}{l}\text { Shrub } \\
\text { grass }\end{array}$ & $\begin{array}{l}\text { Mars } \\
\text { hy } \\
\text { grass } \\
\text { land }\end{array}$ & & desert & $\begin{array}{l}\text { bare } \\
\text { area }\end{array}$ & $\begin{array}{c}\text { river } \\
\text { system }\end{array}$ & $\begin{array}{c}\text { Glacier } \\
\text { snow }\end{array}$ \\
\hline Food & 0.85 & 1.36 & 0.22 & 0.31 & 0.29 & 0.19 & 0.1 & 0.38 & 0.22 & 0.51 & 0.01 & 0 & 0.8 & 0 \\
\hline Material & 0.4 & 0.09 & 0.52 & 0.71 & 0.66 & 0.43 & 0.14 & 0.56 & 0.33 & 0.5 & 0.03 & 0 & 0.23 & 0 \\
\hline Water & 0.02 & -2.63 & 0.27 & 0.37 & 0.34 & 0.22 & 0.08 & 0.31 & 0.18 & 2.59 & 0.02 & 0 & 8.29 & 2.16 \\
\hline Air regulation & 0.67 & 1.11 & 1.7 & 2.35 & 2.17 & 1.41 & 0.51 & 1.97 & 1.14 & 1.9 & 0.11 & 0.02 & 0.77 & 0.18 \\
\hline $\begin{array}{c}\text { Climate } \\
\text { regulation }\end{array}$ & 0.36 & 0.57 & 5.07 & 7.03 & 6.5 & 4.23 & 1.34 & 5.21 & 3.02 & 3.6 & 0.1 & 0 & 2.29 & 0.54 \\
\hline $\begin{array}{c}\text { Waste } \\
\text { treatment }\end{array}$ & 0.1 & 0.17 & 1.49 & 1.99 & 1.93 & 1.28 & 0.44 & 1.72 & 1 & 3.6 & 0.31 & 0.1 & 5.55 & 0.16 \\
\hline $\begin{array}{c}\text { Water } \\
\text { regulation }\end{array}$ & 0.27 & 2.72 & 3.34 & 3.51 & 4.74 & 3.35 & 0.98 & 3.82 & 2.21 & 24.23 & 0.21 & 0.03 & 102.24 & 7.13 \\
\hline $\begin{array}{c}\text { Maintenance } \\
\text { of soil } \\
\text { formation }\end{array}$ & 1.03 & 0.01 & 2.06 & 2.86 & 2.65 & 1.72 & 0.62 & 2.4 & 1.39 & 2.31 & 0.13 & 0.02 & 0.93 & 0 \\
\hline $\begin{array}{l}\text { Nutrient } \\
\text { cycling }\end{array}$ & 0.12 & 0.19 & 0.16 & 0.22 & 0.2 & 0.13 & 0.05 & 0.18 & 0.11 & 0.18 & 0.01 & 0 & 0.07 & 0 \\
\hline $\begin{array}{l}\text { Maintenance } \\
\text { of biodiversity }\end{array}$ & 0.13 & 0.21 & 1.88 & 2.6 & 2.41 & 1.57 & 0.56 & 2.18 & 1.27 & 7.87 & 0.12 & 0.02 & 2.55 & 0.01 \\
\hline $\begin{array}{c}\text { Spiritual \& } \\
\text { Cultural values }\end{array}$ & 0.06 & 0.09 & 0.82 & 1.14 & 1.06 & 0.69 & 0.25 & 0.96 & 0.56 & 4.73 & 0.05 & 0.01 & 1.89 & 0.09 \\
\hline
\end{tabular}

\section{Copyrights}

Copyright for this article is retained by the author(s), with first publication rights granted to the journal.

This is an open-access article distributed under the terms and conditions of the Creative Commons Attribution license which permits unrestricted use, distribution, and reproduction in any medium, provided the original work is properly cited. 